\title{
Yapısal Kırılmalar Altında Ticari Açıklığın ve Doğrudan Yabancı Sermaye Yatırımlarının İstihdam Üzerindeki Etkisinin İncelenmesi: E7 Ülkeleri Örneği \\ Seda BAYRAKDAR ${ }^{1}$ Semanur SOYYİĞiT ${ }^{2}$
}

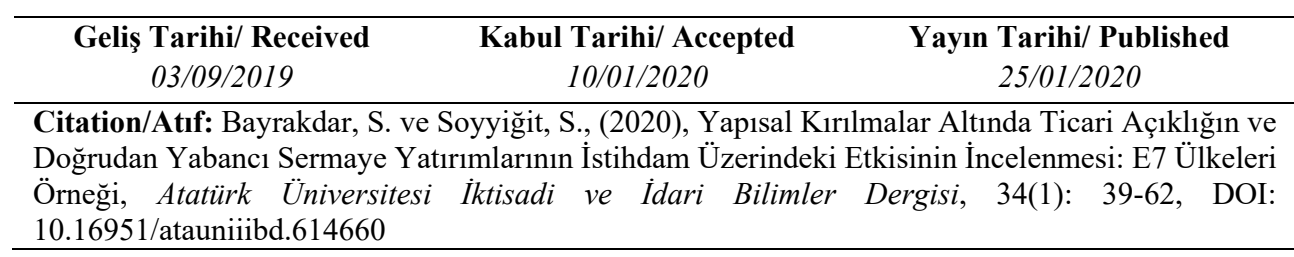

Öz: Ülkelerin küresel değer zincirine adapte olmalarının iki önemli bileşeni, ülkeye giren doğrudan yabancı sermaye yatırımları ve ticari açıklıktır. Ülkelerin küresel ekonomi ile bütünleşme faaliyetlerinin altında, bu faaliyetlerin ülke ekonomisine olumlu katkı sağlaması beklentisi yer almaktadır. Kuşkusuz bu iki iktisadi faaliyet, bir ülkedeki birçok makroekonomik göstergeyi de etkilemektedir. Bu makroekonomik göstergelerin en önemlilerinden biri ise istihdamdır.

$\mathrm{Bu}$ kapsamda, bu çalışmada E7 ülkeleri için ticari açıklık ve doğrudan yabancı sermaye yatırımlarının GSYH'deki payının istihdam üzerindeki etkisi incelenmektedir. 1993-2017 dönemini kapsayan çalışma sonucunda, ticari açıklık ve istihdam arasında uzun dönemli bir ilişki tespit edilemezken; doğrudan yabancı sermaye yatırımlarının GSYH'deki payı ile istihdam arasında uzun dönemli bir ilişki tespit edilmiştir. Yapısal kırılmalar altında yapılan eşbütünleşme analizi sonucunda doğrudan yabancı sermaye yatırımı değişkeninin istihdam değişkeni üzerinde Çin, Endonezya ve Rusya için pozitif; Brezilya ve Hindistan için ise negatif etkiye sahip olduğu bulgusu elde edilmiştir. Türkiye ve Meksika için istatistiksel olarak anlamlı bir sonuç elde edilememiştir. Yapısal kırılma sonuçları incelendiğinde ise, analiz bulguları bu iki değişken arasındaki uzun dönemli ilişkinin E7 ülkelerinde hem küresel hem de ülkelere özgü krizlerden etkilendiğini ortaya koymaktadır.

Anahtar kelimeler: İstihdam, Ticari Açıklık, Doğrudan Yabancı Sermaye Yatırımları, Eşbütünleşme Analizi

Analysis of the Impacts of Trade Openness and Foreign Direct Investments on Employment under Structural Breaks: the Case of $\mathbf{E} 7$ Countries

Abstract: Two prominant components of countries' integration to the global value chain are the foreign direct investments and trade openness. Under the integration activities of countries with the global economy, there is the expectation that these activities will contribute positively to the national economy. Undoubtedly, these two economic activities affect many macroeconomic indicators in a country. One of the most important of these macroeconomic indicators is employment.

${ }^{1}$ Dr. Öğr. Üyesi, Kırıkkale Üniversitesi, İktisadi Ve İdari Bilimler Fakültesi, İktisat Bölümü, https://orcid.org/0000-0003-3879-6561

${ }^{2}$ Dr. Öğr. Üyesi, Erzincan Binali Yıldırım Üniversitesi İktisadi ve İdari Bilimler Fakültesi, İktisat Bölümü, https://orcid.org/0000-0002-5679-6875 
Yapısal Kırılmalar Altında Ticari Açıklı̆̆ın ve Doğrudan Yabancı Sermaye Yatırımlarının İstihdam Üzerindeki Etkisinin İncelenmesi: E7 Ülkeleri Örneği

Within this scope, the present study examines the impact of trade openness and the share of foreign direct investment in GDP on employment for E7 countries. As a result of the study covering the period 1993-2017, no long-term relationship between trade openness and employment variables has been determined, while a long-term relationship has been identified between the share of foreign direct investment in GDP and employment. As a result of the cointegration analysis conducted under structural breaks, the impact of foreign direct investment variable on employment has been positive for China, Indonesia and Russia on the employment variable while it has been found to have a negative effect for Brazil and India. No statistically significant relationship has been found for Turkey and Mexico. When structural break date results are analyzed, findings reveal that the long-term relationship between these two variables is affected by both global and country-specific crises for E7 countries. Keywords: Employment, Trade Openness, Foreign Direct Investments, Cointegration Analysis

\section{EXTENDED ABSTRACT}

As well as it is important for developing countries to participate in global value chain in order to provide economic development, this process is required to be associated by structural transformation. Otherwise, benefits that developing countries get from the process will be limited. It is required for these countries to enhance their positions on this purpose. This enhancement also requires coordination of different kind of policies such as infrastructure policies, trade policies, industrial policies, labor policies etc. (Gereffi, 2015: 20-22).

Two important parts of integration with global value chain are inflow of foreign direct investments and trade openness. The integration activities of countries with global economy depend on expectancy of receiving benefit for the national economy. Undoubtedly, these activities, namely foreign direct investments and trade openness, have impact on a lot of macroeconomic indicators. One of these important macroeconomic indicators is employment. In economies in which manage this structural transformation and integrate with the global economy succesfully, employment rate will be affected positively.

Within this scope, the main motivation of the present study is to examine the impact of trade openness and share of foreign direct investment in GDP on employment for Emerging 7 (E7) countries. The analysis covers the period from 1993 to 2017. The main reason to chose E7 countries is that these countries are evaluated as driving force of the global economic growth. Because E7 countries, which consist of China, Brazil, Mexico, India, Indonesia, Russia and Turkey, are estimated to increase their share in global income to $50 \%$ by $2050^{3}$.

We have examined two models in which the independent variables are 'foreign direct investment/GDP' ratio and trade openness, and the dependen variable is employment rate. Then, we applied cointegration analysis to examine long-term relationship between the variables. Cross-section dependence test revealed that both the series and the residuals belong to the models have cross-sectional dependence. This result affected our choice for unit-root test and cointegration test. We applied Multivariate ADF (MADF) test for the series. Westerlund (2006) test with multiple

${ }^{3}$ Çevrimiçi, https://www.pwc.com.tr/tr/publications/arastirmalar/assets/world-in-2050/2050de-dunya-raporu.pdf, (01.01.2020). 
structural breaks and Durbin-Hausman tests are applied to examine the existence of cointegration.

Cointegration analysis revealed that there was not a long term relationship between trade openness and employment rate while there was long term relationship between 'foreign direct investment/GDP' ratio and employment rate. This long term relationship was positive for China, Indonesia and Russia while it was negative for Brazil and India. There was not a significant long term relationship for Turkey and Mexico. When it comes to structural breaks, analysis revealed for E7 countries that the long term relationship between the share of foreign direct investments in GDP and employment rate were affected by both local and global crises.

We investigated sectoral distribution of foreign direct investment in order to explain the negative relationship between the variables for Brazil and India. When cumulative sectoral distribution of foreign direct investment from 2000 to 2019 are analyzed for India, it is observed that services sector ranks first with $17.6 \%$ share, computer software sector ranks second with $8.5 \%$, construction ranks third with $5.7 \%$ share and trade sector ranks fourth with $5.5 \%$ share ${ }^{4}$. It can be evaluated that the foreign direct investment in India centered on services rather than productive manufacturing sector. Brazil also has similar situation. The share that trade sector takes from foreign direct investments rises from $12 \%$ in 2010 to $17 \%$ in 2015 . The share that financial services sector takes from foreign direct investments rises from $6 \%$ in 2010 to $10 \%$ in 2015. Information and technology services have 5\% share and construction activities have $4 \%$ share in 2015 . The share of real estate sector is $10 \%$ in 2015 (Banco Central do Brasil, 2018: 23).

In conclusion, the results of the present study reveals that it is also an important factor in which sectors foreign direct investment inflows operate as well as the volume of the investment. Especially, when the impact of foreign direct investment on employment is taken into consideration, it becomes prominant to encourage investments for productive sectors.

\section{Giriş}

Küreselleşme, dünyada kültürel, siyasi ve ekonomik anlamda ülkeler arasındaki kısıtlamaların azalması, ülkelerin artan bir şekilde bütünleşmesi, benzeşmesi, ülkeler arasındaki mesafelerin öneminin azalması, ortak değerlerin ön plana çıkmasıdır. Ekonomik bakımdan küreselleşme sürecinin önemli göstergelerinden birini dışa açıklık oluşturmaktadır. Dışa açıklık, finansal açıklık ve ticari açıklık şeklinde kategorize edilebilir. Ekonomideki serbestleşmenin göstergesi olarak kullanılan ticari açıklık kamu müdahalesi nedeniyle ticaretteki tarife, vergi, ek ücretler, politikaların kolaylaştırıcı yönde değişmesi anlamına gelir. Birçok ölçüm yöntemi olan ticari açıklık oranı yaygın olarak çalışmalarda ülkenin ithalat ve ihracat toplamının yine o ülkenin zenginliğinin bir göstergesi olan gayri safi yurtiçi hasılaya (GSYH) bölünmesi ile elde edilmektedir. Bunun yanında finansal açıklık ise finans

${ }^{4}$ Çevrimiçi, https://dipp.gov.in/sites/default/files/Table_No_4_JULY_19.pdf (31.12.2019) 
Yapısal Kırılmalar Altında Ticari Açıklı̆̆ın ve Doğrudan Yabancı Sermaye Yatırımlarının İstihdam Üzerindeki Etkisinin İncelenmesi: E7 Ülkeleri Örneği

piyasalarındaki her türlü kısıtlamanın veya engelin azaltılması ya da ortadan kaldırılması şeklinde ifade edilebilir. Çalışmada, küreselleşmenin göstergelerinden olan finansal açıklıkla ilintili olarak seçilmiş veri doğrudan yabancı sermaye yatırımlarının GSYH'deki payı, ticari açıklık ile ilgili olarak seçilmiş veri ise mal ve hizmet ticaretinin GSYH içindeki payıdır.

$\mathrm{Bu}$ iki önemli ölçüt ekonominin diğer makro dinamiklerini (ekonomik büyüme- kalkınma, istihdam, işsizlik) büyük oranda etkileyecektir. $\mathrm{Bu}$ etki, günümüzde ve gelecekte artan küreselleşme ile ilişkili olarak, elde edilen avantajların yanında artan sorunlar şeklinde ülkelerin gündemini meşgul etmektedir/edecektir. Bu etkilerin başında, istihdam olanaklarındaki değişim yer almaktadır. Dolayısıyla, küreselleşmenin bir unsuru olan dışa açıklığın önemli bir diğer makroekonomik gösterge olan istihdam üzerindeki etkisi araştırılmaya değerdir.

Çalışmada, istihdam değişkeni ile ticari açıklık ve doğrudan yabancı sermaye yatırımlarının GSYH içindeki payı arasındaki ilişki, E7 ülkeleri için incelenmektedir. İncelenen ülke grubu, E7 ülkeleri olarak adlandırılan "Emerging 7" bir başka deyişle gelişmekte olan yedi ülkedir. Bu ülkeler: Çin, Hindistan, Brezilya, Rusya, Endonezya, Meksika, Türkiye'dir. Söz konusu ülkelerin seçilme nedeni, E7 ülkelerinin şu andaki ve gelecekteki olası konumundan kaynaklanmaktadır. Bu ülkeler, son 20 yılda büyük gelişme göstermiş ve dünyanın en güçlü ekonomileri içerisine girmişlerdir. PricewaterhouseCoopers $(\mathrm{PwC})$ şirketinin yayınladığ $\mathrm{The}$ World in 2050 Raporuna $^{5}$ göre gelişmekte olan piyasalar küresel ekonominin büyüme motoru olmaya devam edeceklerdir. 2050 yılında $\mathrm{E} 7$ ekonomileri dünyadaki GSYH paylarını \%35' den \%50'ye çıkarabilirler. Çin 2050'de dünyanın en büyük ekonomisi olabilir ve dünya GSYH 'nın yaklaşı \%20'sini oluşturacaktır. İkinci ve dördüncü sırada Hindistan ve Endonezya yer alabilir.E7 ülkelerinin 2050 y1lına kadar her yıl yaklaşık $\% 3,5$ büyümesi beklenmektedir. Bu oran dünyanın en gelişmiş ekonomileri olarak kabul edilen G7 (ABD, Kanada, İtalya, Fransa, İngiltere, Japonya, Almanya) için beklenilen büyüme oranının yaklaşık \%1,6'nın üzerindedir. Raporda 2050 yılında dünyanın en büyük ekonomileri sırası ile Çin, Hindistan, $\mathrm{ABD}$, Endonezya, Brezilya, Rusya, Meksika, Japonya, Almanya, İngiltere olarak belirtilmiştir. Bu sebeplerle çalışmada söz konusu ülke grubu tercih edilmiştir.

İlk kısımda, yapılan analizin teorik dayanağı faktör donatımı teorisi ve Ricardian model ve McKinnon-Shaw hipotezi bağlamında anlatılmakta; dışa açıklık ve istihdam ilişkisinin teorik çerçevesi, konu ile ilgili gerekli tanımlar ve kavramlar açıklanmaktadır. İkinci kısımda ise daha önce konu ile ilgili olarak yapılan çalışmalardan seçilmiş örneklere yer verilmektedir. Üçüncü kısımda, çalışmanın hipotezi ve analizde kullanılan değişkenler; dördüncü kısımda ise izlenen

\footnotetext{
${ }^{5}$ Detaylı bilgi için PricewaterhouseCoopers (PwC) (2017). The Long View How Will the Global Economic Order Change by 2050?, (çevrimiçi)

https://www.pwc.com.tr/tr/publications/arastirmalar/assets/world-in-2050/2050-de-dunya-raporu.pdf, (01.01.2020).
} 
ekonometrik metodoloji açıklanmaktadır. Çalışmanın beşinci kısmında, analiz sonucunda elde edilen bulgular sunulmakta; altıncı kısımda ise sonuç ve değerlendirmeye yer verilmektedir.

\section{Dışa Açıklık Ve İstihdam İlişskisi: Teorik Çerçeve}

Ekonomideki ticari serbestleşme yani ticari açıklığın oranı, kamu müdahalesinden kaynaklanan ticaretin zorlaştırılması ya da engellenmesine yönelik tarife, vergi, ek ücretler, politikaların değişmesi anlamına gelir (Özel, 2012: 23-24). Ticari açıklığın ölçülmesinde farklı yöntemler kullanılabilir. Bu yöntemlerden başlıcaları (Özel, $2012: 24)$ :

- Ticari bağımlılık (açıklık) oranı: (İhracat+ İthalat)/GSYH

- İhracatın büyüme oranı: bir zaman dilimi içerisindeki ihracatın büyüme hacmi

- Tarife ortalamaları: basit ya da ağırlıklandırılmış tarifelerin seviyesi

- Birikimli tarife oranlar1: tarife gelirleri/ ithalat

- Nicel kısıtlamalar: nicel kısıtlamaları kapsayan malların yüzde değeri

- Karaborsa primi: dış sektördeki çarpıklıkları gösterir döviz fiyatı

- Ticari eğilim endeksi: ithal edilen mal fiyatları ihraç edilen mal fiyatlarına nispeten artış gösterirse, bu oran dünya piyasalarıyla mukayese edilmektedir.

- Sachs ve Warner İndeksi: Sosyal organizasyonlar ve ihraç mallarında resmi kurumların oran1, ticaret tarifeleri, kota oranları, karaborsa primi gibi bileşenlerden oluşmaktadır.

- Leamer Açıklık İndeksi: teorik modelleme ile beklenilen ticaret ile gerçekleşen ticaret arasında oluşabilecek fark tespit edilmeye çalışılır.

Genel olarak ticari açıklığı ölçmede tekrara ve çıktıya dayalı yöntemler kullanılırken, tekrara dayalı yöntem tarife dışı sınırlamaları modele dahil etmemesi nedeniyle yaygın olarak tercih edilmemektedir. Genelde ticari açıklık seviyesini ölçmede kullanılan çıktıya dayalı yöntemde, sıklıkla ülkenin ithalat ve ihracatı toplanarak GSYH'ye bölünür (Spilimbergo vd., 2003: 305). Teorik tartışmalar uyarınca ticari açıklık ve istihdam ilişkisi Ricardian hipotez ve Heckscher- Ohlin (HO) modeli üzerinden kurgulanabilir. Ricardian hipotezde, daha fazla ticaretin istihdamı artırabileceği, çünkü ihraç edilebilir kalemleri üreten faktörün emek olduğu ifade edilirken; H-O modelinde ise emek yoğun bir ülkede emek yoğun bir ihracatta istihdamın bundan olumlu etkilenebileceği, fakat sermaye yoğun ihracatta istihdamın düşebileceği öne sürülmektedir (Alkhateeb vd. 2017: 60). Diş ticaretin istihdamı nasıl etkileyeceği ticarete konu malların üretildiği teknolojik yoğunluğa bağlıdır. Gelişmiş ve gelişmekte olan ülkelerin dış ticaretini konu alan H-O teoreminde ülkelerin nispeten daha fazla sahip oldukları üretim faktörleri ile üretilebilecek malların üretiminde uzmanlaşıp, bu malların ticaretini yapmaları konusu üzerinde durulmaktadır. Bu sayede, dış ticaretin istihdama katkısı ortaya çıkmaktadır. Gelişmekte olan ülkelerin sahip olduğu üretim faktörü olan emeğin dış ticarette diğer ülkelere satılması istihdamın artmasına katk1 sağlayacaktır (Jenkins ve Sen, 2006: 300). Ticaretin sektörler arası istihdama olan etkisi bakımından 
Yapısal Kırılmalar Altında Ticari Açıklı̆̆ın ve Doğrudan Yabancı Sermaye Yatırımlarının İstihdam Üzerindeki Etkisinin İncelenmesi: E7 Ülkeleri Örneği

Heckscher- Ohlin- Samuelson (H-S-O) modeli net bir çerçeve sunmaktadır. Ticaret engelleri azaldığında ihracat sektörü genişlerken ithal ikameden ihracata yönelik sektörlere doğru bir kayma olacaktır. Prensip olarak, (diğer bütün koşullar sabitken) artmış ithalat (ihracat) istihdamı azaltma (arttırma) ile ilişkilidir. Emek faktörünün yoğun şekilde kullanıldığı sektörlerde ihracat artışı daha fazla emeğin istihdamına yol açacaktır (Greenaway vd., 1999: 488). Ticari açıklık, birçok bakımdan ekonomik performans ve bununla ilişkili olarak istihdam artışı üzerinde olumlu etkilere yol açabilir. Ticari açılık, teknolojik yenilikleri teşvik ederek, üretimde ölçeğe göre artan getiriye yol açacaktır iddiasında bulunulmaktadır. Ayrıca, faktör fiyatlarındaki farklılık sınır ötesi emek, sermaye, mal- hizmetlerini tetikleyebilir. Üçüncü etki sermaye akımları önemli bir miktarda sermaye girişi sağlayan yatırımlar için başka bir açıklık faktörüdür. Dış ticaretteki açıklı̆ın istihdama etkisi, yabancı firmaların ithalatından daha fazla artan ihracat olanaklarından yararlanan yerli firmaların lehine olacaktır. Küreselleşme ile beraber gelen ticari açıklık, ülkelerin yeni fırsatlar ve faydalar elde etmesine olanak vermektedir. Ülkeler ihracat ile pazar erişimi kazanırlarken uluslararası transferler yoluyla teknoloji de kazanmaktadırlar, imalat faaliyetlerinin sanayileşmiş ülkelerden gelişmekte olan ülkelere yeniden tahsisine devam ederler. Ticari açıklık ulusal ekonomiyi rekabete maruz bırakmaktadır. Ayrıca Smith'in karşılaştırmalı üstünlük teorisine göre açıklık kaynakların etkinlik tahsisini artırmaktadır. Üçüncü olarak ticaret açıklığı ile desteklenen uzmanlaşma uzun vadede ekonomik büyümeyi olumlu etkilemektedir. Diğer yandan acaba ticari açılık işgücü piyasasını olumsuz etkiler mi? Ticari açıklık nedeniyle mal ve hizmet fiyatlarındaki nispi değişiklik ithalata rakip sektörlerde işin değerinde bir kayba yol açarken, ihracat sektöründe iş değerinde bir artışa yol açacaktır. Ayrıca, ihracata yönelik sektörlerdeki ücret eşitsizlikleri artmaktadır ve ticaretin liberalleşmesine bağlı olarak ithalata rekabet eden sektörlerde düşüş olmaktadır (Yılmaz ve Altay, 2016: 828).

Dışa açıklığın bir diğer unsuru olan finansal açıklık ise finansal baskı unsuru taşıyan nitelikteki bütün politikaların minimize edilmesinin yanında yabancı yatırımlara yönelik kısıtlamaların kaldırılmasını ifade eder. Finansal serbestleşme daha fazla yabancı sermayenin önünü açan finansman kısıtlamalarını azaltır ve yabancı yatırımcılar için daha iyi bir kurumsal yönetim sağlayabilir. Yönetişimin iyileştirilmesi, şeffaflık ve hesap verilebilirliği teşvik ederek finansal sistemlerin verimliliğini artırabilir. Gelişmekte olan ekonomilerde liberalleşme ile gelen finansal serbestleşme sermaye akımlarını tetikleyebilir (Yang vd., 2019). Finansal serbestleşmenin teorik temeli ise McKinnon-Shaw hipotezine dayanmaktadır. Hipotez temel dayanağını ödünç verilebilir fonlar teorisinden almaktadır. Hipotezde, finansal olarak serbestleşen ekonomilerde finansal çeşitlilikteki fazlalık sebebiyle tasarruf ve yatırımların arttığ 1 , bu nedenle de ekonomik büyümenin olumlu etkilendiği aynı zamanda sermaye üzerindeki kısıtlamaların ortadan kalkması ile sermaye akışının yüksek getirili alanlara kayması nedeniyle finansal derinliğin artacağı dolayısı ile iç tasarruf artışının büyümeye yol açacağı ifade edilmektedir. 
Yani yatırım, üretim ve ihracat genişlemesi ortaya çıkacaktır (Kıran ve Güriş, 2011:70).

\section{Seçilmiş Literatür Taraması}

Seçili literatür taraması iki kısımdan oluşmaktadır. İlk kısımda dışa açıklığın birinci unsuru olarak kabul edilen ticari açıklık ve istihdam ilişkisini araştıran yazına, ikinci kısımda ise dışa açıklığın ikinci unsuru olarak kabul edilen finansal açıklığın istihdam ile ilişkisini, bu çalışmada da kullanıldığı gibi doğrudan yabancı sermaye yatırımları üzerinden araştıran yazına yer verilmiştir.

Lee ve Roland-Holst (1994) Tayvan, Endonezya, ABD, Japonya, Çin, Güney Kore, Singapur, Malezya, Tayland, Filipinler'i içeren Pasifik Asya ülkeleri için yaptıkları analizde, gelişmiş ülkelerde ithal mallarına olan talep artışının gelişmekte olan ülkelerdeki istihdam oranlarını olumlu etkileyeceği tespitine ulaşmıştır. Çalışmada tarife ve tarife dışı engellerin kaldırılması üzerinden yapılacak ticaret hacmi artışı, istihdam hacmini de olumlu etkileyecektir denilmektedir. Baldwin (1995) OECD ülkeleri için ticaretin istihdam üzerindeki etkisini ve doğrudan yabancı yatırım verilerini de modele dahil ederek incelemiştir. Ticaretteki artışa neden olan ithalat artışının işsizlik hadlerini yükseltici bir etki yaratacağı sonucuna ulaşılmıştır. Buna ilave olarak doğrudan yabancı yatırımların işgücü verimliliğini olumlu yönde etkilediğini tespit etmiştir. Taymaz (1999) Türkiye için yapmış olduğu çalışmada özellikle 24 Ocak 1980 kararları ile ekonomideki liberalleşmenin sonucunda yüksek reel faiz ve reel döviz kuru kanalından imalat sanayinin istihdam verimliliğine etki yapacağını bulmuştur. Greenaway vd. (1999) İngiltere ekonomisi için 1979-1991 yılları arasındaki dönemde dışa açıklık ve istihdam ilişkisini incelerken, İngiltere'de ihracattaki \%1'lik bir artışın kısa dönemde sanayi istihdamını \%3,8; uzun dönemde ise $\% 4.71$ oranında azalttığını tespit etmiştir. Şener (2001), dış ticaret ve istihdam ilişkisinin yönüne ilişkin tam bir tespit yapılamayacağını, dış ticaretin istihdam üzerindeki etkisinin ülkenin sahip olduğu vasıflı işgücüne bağlı olduğunu ifade etmiştir. Dışa açılma vasıflı işgücü istihdamını pozitif etkilerken, vasıfsız işgücü istihdamını ise negatif etkiler denilmektedir. Janiak (2006) 1974-1988 yılları arasında ABD ekonomisi için dış ticaret ve istihdam ilişkisini 418 sektör bazında Genelleştirilmiş Momentler yöntemini (GMM) kullanarak analiz etmiştir. Çalışmanın sonucunda, ticari serbestleşmenin istihdamı azalttığı bulgusuna ulaşılmıştır. Bunun nedeni olarak artan diş ticaretin yarattığı iş imkânlarından daha çoğunu yok etmesi gösterilmektedir. Jenkins (2006), yabancı firmaların ihracat ve sanayi çıktısındaki önemli rolüne rağmen, doğrudan istihdam üretme etkisinin oldukça sınırlı kaldığı tespitine ulaşmıştır. Bu etkinin sebebi olarak, yüksek emek verimliliği ve yatırımın çoğu çıktısındaki düşük katma değer oranı gösterilmektedir. Makalede doğrudan yabancı sermaye yatırımlarının dolaylı istihdam üzerindeki etkisinin, yabancı yatırımcıların yarattığı sınırlı bağlantılar ve yerel yatırımların dişlanması nedeniyle, minimal ve muhtemelen olumsuz olduğu iddia edilmektedir. Asiedu ve Brempong (2008) makalelerinde küreleşmenin bir yönü olan yatırım politikalarındaki serbestleşmenin, 1984-2003 döneminde 33 ülke 
Yapısal Kırılmalar Altında Ticari Açıklı̆̆ın ve Doğrudan Yabancı Sermaye Yatırımlarının İstihdam Üzerindeki Etkisinin İncelenmesi: E7 Ülkeleri Örneği

verilerini kullanarak dinamik panel veri analizi ile, çok uluslu şirketlerin Afrika'daki yatırım ve istihdama etkisini analiz etmektedir. Çalışma neticesinde iki önemli sonuca ulaşılmıştır. Bunlardan ilki, küreselleşmenin yatırımları pozitif etkilediği; diğeri ise çokuluslu istihdam üzerinde doğrudan bir etkisi bulunmamakla beraber serbestleşmenin dolaylı olarak istihdamı ve yatırımları artırdığı biçiminde ifade edilmektedir. Kien ve Heo (2009), 1999-2004 yılları arasında Vietnam için GMM ile ticari serbestleşmenin istihdama etkisini araştırmıştır. Sanayi üretimindeki artışın emek talebini artırdığı, artan ücret oranlarının ise emek talebini düşürdügü sonucuna ulaşılmıştır. İhracat genişlemesi nedeniyle istihdam hacmi arasındaki ilişki istatistiksel olarak anlamlı ve pozitiftir. İthalatın ise Vietnam'daki istihdam seviyesini olumsuz etkilemediği tespit edilmiştir. Ayaş ve Çeştepe (2010), 19982002 yılları arasında girdi-çıktı tabloları kullanılarak dış ticaret değişimlerinin istihdam üzerindeki etkileri incelenmiş, bu etkinin sektörler itibariyle farklı sonuçlara yol açtığı ifade edilmiştir. Sonuç itibariyle imalat sanayinde üretim ve istihdamın büyük ölçüde ithal girdiye bağımlı olduğu sonucuna ulaşılmıştır. Polat ve Uslu (2010) çalışmalarında 1998-2007 yılları arasındaki dönemi çeyrek dönemlik verilerle incelemiş ve uzun dönemde dış ticaretin istihdam üzerinde anlamlı bir etkisi olmadığı, kısa dönemde ise hem ihracatın hem de ithalatın istihdam üzerinde pozitif anlamlı bir etkisi olduğu sonucuna ulaşmışlardır. Karaçor ve Saraç (2011) 24 Ocak kararları ile sanayi sektörü istihdam hacmi arasındaki ilişkiyi incelemiş, alınan tedbirlerin ardından sanayi sektöründeki istihdam hacminin yüksek faiz ve enflasyon sarmalı nedeniyle azaldığını tespit etmişlerdir. Hasan vd. (2012), 1987-2005 yılları arasındaki dönemi dört ayrı zaman diliminde inceleyerek (1987-1988, 1993-1994, 1999-2000, 2004-2005) Vektör Hata Düzeltme Modeli (VECM) ve Granger nedensellik testleri uygulamıştır. Hindistan'da ticari açıklığın kent istihdamını arttırdığını tespit etmiştir. Gül ve Kamacı (2012), gelişmiş ve gelişmekte olan ülkeler ${ }^{6}$ bazında bir ayrıma giderek, 1980-2010 ve 1993-2010 dönemleri için Pedroni eşbütünleşme testi ve Granger nedensellik testi yapılmıştır. Ortaya çıkan analiz neticesinde her iki ülke grubu için uzun dönemde eşbütünleşme ilişkisi tespit edilmiştir. Ayrıca, nedensellik sonuçları uyarınca işsizlikten ithalat-ihracata doğru bir ilişki bulunamazken, tam tersi durumda yani ithalat ve ihracattan işsizliğe doğru bir nedensellik ilişkisine ulaşılmıştır. Sandalcılar ve Yalman (2012) Türkiye özelinde ticari açıklık ve emek piyasası arasındaki ilişkiyi Granger ve Hsiao nedensellik ve eşbütünleşme testleri ile analiz etmişlerdir. 1980-2010 yılları arası dönemi kapsayan analiz sonucunda Türkiye'de ticari açıklığın emek piyasalarını negatif etkilediği sonucuna ulaşılmıştır. Yanıkkaya (2013) gelişmiş ve gelişmekte olan ülkeler bazında yaptığı araştırmada 1980-2009 yılları arasındaki dönemi ele alarak panel Görünürde İlişkisiz Regresyon (Seemingly Unrelated Regression-SUR) yöntemini kullanmıştır. Çalışmada yüksek ticaret hacimleri şeklinde ortaya çıkan

${ }^{6}$ Gelişmiş ülkeler: ABD, Almanya, Avustralya, Hollanda, İngiltere, İrlanda, İspanya, İsviçre, İtalya, Japonya, Kanada ve Güney Kore. Gelişmekte olan ülkeler: Letonya, Litvanya, Meksika, Romanya, Şili, Türkiye ve Kazakistan. 
ticari açıklığın, gelişmekte olan ülkelerde iş yaratmada başarılı olmadığı ifade edilmektedir. Buna ilaveten yüksek ticaret hacimlerinin, gelişmiş ülkelerdeki sanayi istihdamını olumsuz etkilediğine dikkat çekilmiş, gelişmekte olan ülkelerde ise sanayi ve hizmetler sektöründe olumlu etkiler yarattığ1 söylenmiştir. Sonuç olarak ticari açıklığın kendi içerisinde gelişmekte olan ülkelerin işsizlik sorununa bir çözüm olmadığı belirtilmiştir. Gozgor (2013) 1993-2008 yılları arasındaki dönemi G7 ülkeleri için ele almış, modelde GMM yöntemini kullanarak ticari açıklığın istihdamı arttıran bir etkiye sebep olduğunu ve işsizliği azalttığını belirtmiştir. Goaied ve Sassi (2015) Tunus'ta 1983-2010 yılları arasında panel veri analizi yöntemi ile serbest ticaret anlaşması sürecinin öncesi ve sonrasındaki dönem için 15 sektör bazında istihdam ile olan etkileşimi araştırılmıştır. Serbest ticaret anlaşması ile beraber bilhassa emek yoğun sektörlerde istihdamda önemli düşüşler meydana gelmiştir.

Bütün bu çalışmalara ek olarak, finansal açıklığın bir göstergesi olan ve bu çalışmada da finansal açıklığı temsil eden doğrudan yabancı sermaye yatırımlarının emek piyasası üzerindeki etkisini ölçen seçili çalışmalar incelenecek olursa; Göçer ve Peker (2014) Türkiye, Hindistan ve Çin için yaptıkları Maki Çoklu Yapısal Kırılmalı Eşbütünleşme testinde Türkiye'de doğrudan yabancı yatırımların istihdamı azalttığını, Çin ve Hindistan'da istihdamı artırdığını ortaya koymuşlardır. Küresel ekonomi ve artan ekonomik entegrasyonla beraber Vietnam'daki doğrudan yabanc1 yatırımların istihdama etkisini inceleyen. Megbowon vd. (2016) tarafindan Güney Afrika için 1980-2014 dönemi için zaman serisi yöntemi kullanılarak yapılan çalışmada, doğrudan yabancı sermaye yatırımlarının istihdam ve sermaye oluşumu üzerindeki etkisi analiz edilmiştir. Çalışmanın neticesinde doğrudan yabancı sermaye yatırımlarının istihdama etkisi pozitif fakat son derece önemsiz bulunmuş, sermaye oluşumuna etkisi ise ilişkisiz olarak tespit edilerek herhangi bir nedensellik ilişkisi bulunamamıştır. Doğan ve Can (2016) 1970-2011 yılları arasında doğrudan yabancı yatırımların istihdama etkisini Türkiye özelinde araştırmışlardır. Çalışmada Gecikmesi Dağıtılmış Otoregresif sınır testi (ARDL) kullanılmış ve sonuç olarak doğrudan yabancı yatırımların istihdama etkisinin anlamlı olmadığ 1 , dahas katsayıların anlamsız olmasından dolayı doğrudan yabancı yatırımların istihdamı azalttığ bulunmuştur. ,

\section{Veri ve Hipotez}

Küresel değer zincirindeki artan işbölümü, üretim ve tüketim merkezlerinin küresel anlamda birbirinden farklılaşması sonucunu beraberinde getirmiştir. Özellikle 1990'lar sonrası küresel üretim merkezi, doğrudan yabancı sermaye yatırımları aracılığıyla gelişmiş ülkelerden gelişen ülkelere doğru geçiş gerçekleştirirken; bu merkezlerde üretilen ürünler ise büyük ölçüde gelişmiş ülkelerden oluşan tüketim merkezlerine geçiş sürecinde küresel ticaret hacminin artışını beraberinde getirmiştir. Gelişen ülkeler açısından bakıldığında, gerek ticari anlamda gerek doğrudan yabancı sermaye girişi anlamında küresel dünyaya entegrasyon, birçok makro ekonomik gösterge açısından da önemli sonuçlar 
Yapısal Kırılmalar Altında Ticari Açıklı̆̆ın ve Doğrudan Yabancı Sermaye Yatırımlarının İstihdam Üzerindeki Etkisinin İncelenmesi: E7 Ülkeleri Örneği

doğurabilecek nitelik sergilemektedir. Bu amaçla, bu çalışmada ticari açıklığın ve doğrudan yabancı sermaye yatırımlarının önemli bir makro ekonomik gösterge olan istihdam üzerindeki etkisi, gelişen ekonomiler olarak isimlendirilen E7 ülkeleri açısından incelenmektedir.

Gelișen ülkelere daha geniş kapsamla yaklaşılması gerektiği düşüncesinden hareketle BRIC (Brezilya, Rusya, Hindistan ve Çin) ülkelerine Endonezya, Meksika ve Türkiye'nin eklenmesiyle oluşan E7 ülke topluluğuna ilişkin olarak, 2050 y1lı itibariyle mevcut G7 ülkelerinden \%50 daha fazla ekonomik büyüklüğe sahip olacakları yönünde projeksiyonlar gerçekleştirilmektedir (Hawksworth ve Cookson, 2008:2). Dolayısıyla, önemli bir büyüme potansiyeline sahip olan bu ülke topluluğunun, küresel değer zincirine entegrasyon sürecinde makro ekonomik anlamda nasıl etkilendiğinin incelenmesi önem arz etmektedir. Çalışmada incelenen denklemler fonksiyonel olarak aşağıdaki gibi ifade edilebilir:

$$
\begin{gathered}
\text { Model (1): İstihdam = } f(D Y Y) \\
\text { Model (2): İstihdam = } f(A c ̧ \iota k l ı k)
\end{gathered}
$$

$\mathrm{Bu}$ denklemlerden hareketle, ülkelere doğrudan yabancı sermaye girișinin ve ülkelerin ticari açıklıklarının istihdam değişkeni ile ilişkisinin incelenmesi, çalışmanın temel motivasyonunu oluşturmaktadır. Denklemlerde yer alan değişkenlere ilişkin detaylı açıklama Tablo 1'de verilmektedir.

Tablo 1: Değişken tanımı ve kaynă̆

\begin{tabular}{|l|l|c|}
\hline \multicolumn{1}{|c|}{ Değişken } & \multicolumn{1}{|c|}{ Değişen açıklaması } & Veri kaynağı \\
\hline İstihdam & $\begin{array}{l}\text { 15 yaş üstü istihdam edilen nüfusun toplam } \\
\text { nüfus içindeki payının logaritması }\end{array}$ & Dünya Bankası \\
\hline DYY & $\begin{array}{l}\text { Ülkedeki DYY stokunun GSYH'deki payının } \\
\text { logaritması }\end{array}$ & $\begin{array}{c}\text { UNCTAD ve Dünya } \\
\text { Bankası }\end{array}$ \\
\hline Açıklık & $\begin{array}{l}\text { Mal ve hizmet ticaretinin GSYH'deki payının } \\
\text { logaritması }\end{array}$ & Dünya Bankası \\
\hline
\end{tabular}

$\mathrm{Bu}$ değişkenlere ait tanımlayıcı istatistikler ise Tablo 2'de yer almaktadır. Buna göre; her bir değişkene ait gözlem sayısı 175'tir. İstihdamın, doğrudan yabanc1 yatırımların GSYH'deki payının ve ticari açıklı̆ın logaritmalarına ait ortalama değerler sırayla 1.761, 0.164 ve 1.63'tür. Standart sapma değerlerinin küçük olması, serilerin değişkenliğinin düşük olduğunu ifade etmektedir.

Tablo 2: Tanımlayıcı istatistikler

\begin{tabular}{|l|c|c|c|c|c|}
\hline Değiş̧kenler & $\begin{array}{l}\text { Gözlem } \\
\text { sayısı }\end{array}$ & Ortalama & $\begin{array}{l}\text { Standart } \\
\text { sapma }\end{array}$ & $\begin{array}{l}\text { En küçük } \\
\text { değer }\end{array}$ & $\begin{array}{l}\text { En büyük } \\
\text { değer }\end{array}$ \\
\hline İstihdam & 175 & 1.761 & 0.059 & 1.611 & 1.885 \\
\hline DYY & 175 & 0.164 & 0.098 & 0.000 & 0.439 \\
\hline Açıklık & 175 & 1.630 & 0.157 & 1.194 & 1.983 \\
\hline
\end{tabular}

Veri erişilebilirliği nedeniyle 1993-2017 dönemi ile kısıtlı tutulan çalışmada, öncelikle değişkenlere hangi kuşak birim kök testi uygulanması gerektiğine karar vermek üzere yatay kesit bağımlılığı testi uygulanmıştır. Bütün değişkenlerin yatay kesit bağımlılığı olduğu tespit edildikten sonra, uygun birim kök testlerinin 
uygulanması sonucunda istihdam ve DYY değişkenlerinin birinci farkında, açıklık değişkeninin ise düzeyde durağan olduğu tespit edilmiştir. Durağanlık mertebeleri belirlenen değişkenlerin Model (1) ve Model (2)'de belirtilen ilişkiler kapsamında uzun dönemli ilişkilerini test etmek amacıyla sırayla Westerlund ve DurbinHausman eşbütünleşme testleri uygulanmıştır. Test sonucunda İstihdam ve DYY değişkenleri arasında yapısal kırılma altında eşbütünleşme ilişkisi olduğu bulgusu elde edilmiştir ve uzun dönem katsayıları AMG yöntemi ile tahmin edilmiştir. Elde edilen bulguların detaylı biçimde sunulmasından önce, izleyen kısımda takip edilen ekonometrik metodolojiye ilişkin bilgi verilmektedir.

\section{Ekonometrik Metodoloji}

Panel veri analizinde serilerin durağanlığını test etmek için kullanılan birim kök testleri, serilerde yatay kesit bağımlılık olup olmamasına göre farklılık göstermektedir. Bu nedenle önce serilerde yatay kesit bağımlılık olup olmadığı test edilmelidir. Panel veri analizinde kullanılan serilerdeki yatay kesit bağımlılığın incelenmesi için çeşitli testler geliştirilmiştir. Bu testlerden ilki, Breusch ve Pagan'ın geliştirdikleri Lagrange çarpanı (Lagrange Multiplier - LM) testidir. Panel verinin zaman boyutunun yatay kesin boyutundan büyük olduğu $(\mathrm{T}>\mathrm{N})$ durumda kullanılan LM testine ait test istatistiği $\left(\mathrm{CDLM}_{1}\right)$ Eşitlik (1)'de yer almaktadır (Pesaran, 2004: 4):

$$
C D L M_{1}=T \sum_{i=1}^{N-1} \sum_{j=i+1}^{N} \hat{\rho}_{i j}^{2}
$$

Eşitlik (1)'deki $\hat{\rho}_{i j}^{2}$, kalıntıların ikili korelasyonunun tahminidir. Breusch ve Pagan, yatay kesit bağımlılığının olmadığını belirten sıfır hipotezi altında, $\mathrm{CDLM}_{1}$ test istatistiğinin asimptotik olarak $\chi^{2}$ dağıldığını göstermişlerdir. Bununla birlikte, $N \rightarrow \infty$ olduğu durumda bu testin uygulanabilirliği azalmaktadır. Pesaran, $\mathrm{N}$ ve T'nin büyük değerlerinde de kullanılabilecek bir test geliştirmiştir. CDLM 1 'in ölçeklenmiş versiyonu olan bu teste ait test istatistiği $\left(\mathrm{CDLM}_{2}\right)$, Eşitlik (2)'de verilmiştir (Pesaran, 2004: 5):

$$
C D L M_{2}=\sqrt{\frac{1}{N(N-1)}} \sum_{i=1}^{N-1} \sum_{j=i+1}^{N}\left(T \hat{\rho}_{i j}^{2}-1\right)
$$

Pesaran vd. daha sonra LM testinin değişik bir versiyonu olan bir test geliştirmişlerdir. $\mu_{T i j}$ ve $v_{T i j}^{2}$ sırayla, $(T-k) \hat{\rho}_{i j}^{2}$ teriminin ortalamasını ve varyansını ifade etmek üzere, bu teste ait sapması düzeltilmiş $L M$ istatistiği $\left(L_{\text {adj }}\right)$ Eşitlik (3)'te verilmektedir (Pan vd., 2015: 449):

$$
L M_{a d j}=\sqrt{\left(\frac{2 T}{N(N-1)}\right)} \sum_{i=1}^{N-1} \sum_{j=i+1}^{N} \hat{\rho}_{i j} \frac{(T-k) \hat{\rho}_{i j}^{2}-\mu_{T i j}}{\sqrt{v_{T i j}^{2}}}
$$


Yapısal Kırılmalar Altında Ticari Açıklı̆̆ın ve Doğrudan Yabancı Sermaye Yatırımlarının İstihdam Üzerindeki Etkisinin İncelenmesi: E7 Ülkeleri Örneği

Ekonometrik analize başlamadan önce kullanılan serilerin durağan olduklarından emin olunması önemlidir. Zira durağan olmayan serilerle çalışılması halinde, sahte regresyon durumu ile karşılaşllabilmektedir. Panel veri analizinde durağanlığın tespit edilmesi için kullanılan birim kök testleri ise birinci kuşak testler ve ikinci kuşak testler olmak üzere ikiye ayrılmaktadır. Birinci kuşak testler seride yatay kesit bağımlılı̆̆ (yani birimler arası korelasyon) olmadığ 1 durumda kullanılırken; ikinci kuşak testler ise seride yatay kesit bağımlılı̆̆1 (birimler arası korelasyon) olduğu durumda kullanılmaktadır (Yerdelen Tatoğlu, 2013: 199). Bu çalışmada serilerde yatay kesit bağımlılığı tespit edildiği için, serilere ikinci kuşak birim kök testlerinden MADF ve testi uygulanmıştır. Panel verinin zaman boyutunun yatay kesit biriminden büyük olması durumunda $(\mathrm{T}>\mathrm{N})$ kullanılabilen MADF testi (Brooks, 2014: 547), Taylor ve Sarno (1998) tarafindan geliştirilmiş̧ir. Bu test, otoregresif parametrelerin birimden birime farklı olmasına izin vermektedir (Breuer vd., 2002: 530). $i=1,2, \ldots, N$ paneldeki yatay kesit sayısını ve $t=1,2, \ldots, T$ gözlem sayısını göstermek üzere, Taylor ve Sarno Eşitlik (4)'teki Nx1 boyutlu stokastik vektörden hareket etmişlerdir (Taylor ve Sarno, 1998: 287):

$$
q_{i t}=\mu_{i}+\sum_{j=1}^{k} p_{i j} q_{i t-j}+u_{i t}
$$

Burada, $u_{t}=\left(u_{1 t} \ldots \ldots u_{N t}\right)$ hata teriminin bağımsız olduğu ve normal dağıldığı varsayılmaktadır. Standart tek denklemli ADF birim kök testi, $N$ denklemin her birinin ayrı ayrı tahminini ve Eşitlik (5)'te belirtilen temel hipotezin $\mathrm{N}$ birim için uygulanmasinı gerektirmektedir:

$$
H_{0 i}=\sum_{j=1}^{k} \rho_{i j}=0
$$

Birimlere ait her bir otoregresif sürecin kökünün 1'e yakın; ancak 1'den farklı olduğu durumlarda, tek değişkenli ADF testi zayıf kalmaktadır. Bu nedenle Taylor ve Sarno (1998: 287) Eşitlik (4)'teki denklemi, hata terimleri arasındaki eş-anlı korelasyonu dikkate alarak tahmin etmiş̧lerdir. Sıfır hipotez N denklem için Eşitlik (6)'daki gibi gösterilmektedir:

$$
H_{0}: \sum_{j=1}^{k} \rho_{i j}-1=0, \quad \forall i=1, \ldots, N
$$

$\mathrm{Bu}$ test sonucunda elde edilen Wald istatistiği, MADF istatistiği olarak adlandırılmaktadır. Eşitlik (4)'te yer alan denklemin tahmininde, SUR (seemingly unrelated regression) tahmincisi kullanılmaktadır (Taylor ve Sarno, 1998: 287).

Analizde kullanılan değişkenlere ait serilere birim kök testi uygulanmasının ardından, Model (1)'deki değişkenler arasındaki ilişkiler çok kırılmalı Westerlund eşbütünleşme testi ile, Model (2)'deki değişkenler arasındaki ilişkiler ise ilgili değişkenlerin durağanlık düzeyindeki farklılık nedeniyle Durbin-Hausman eşbütünleşme testi ile incelenmiştir. Durbin-Hausman eşbütünleşme testi 
eşbütünleşme denkleminde yatay kesit bağımlılı̆g 1 tespit edildiğinde ve ayrıca, bağımlı değişken I(1) olmak koşuluyla, bağımsız değişkenlerin I(1) ve I(0) olması durumunda da kullanılabilen bir testtir. Bu testte sıfır hipotez ve alternatif hipotez şu şekilde kurulmaktadır (Göçer, 2013a: 5096):

$$
\begin{aligned}
& H_{0} \text { : Eşbütünleşme ilişkisi yoktur. } \\
& H_{1} \text { : Eşbütünleşme ilişkisi vardır. }
\end{aligned}
$$

Durbin-Hausman testi hem grup boyutunda hem panel boyutunda gerçekleştirilmektedir. Grup boyutunda gerçekleştirilen test otoregresif parametrelerin yatay kesitler arasında farklılaşmasına izin verirken, panel boyutunda gerçekleştirilen test ise otoregresif parametrenin bütün yatay kesitler için aynı olduğu kabulüne dayanmaktadır (Göçer, 2013a: 5096). Bu husus göz önünde bulundurulduğunda; grup boyutundaki Durbin-Hausman testi bütün birimler için eşbütünleşmenin olmadığını ifade eden sıfır hipotezi, bazı birimler için eşbütünleşme olduğunu ifade eden alternatif hipoteze karşı sınanmaktadır. Yani test sonucu elde edilen grup istatistiği, heterojenlik varsayımına dayanmaktadır. Buna karşıllk, panel boyutundaki Durbin-Hausman testi ise panelin genelinde eşbütünleşme olmadığı sıfır hipotezini, panelin genelinde eşbütünleşme olduğu alternatif varsayımına karşı sınamaktadır. Dolayısıyla, panel istatsitiği panelde homojenlik olduğu varsayımına dayanmaktadır.

Çalışmada kullanılan bir diğer eşbütünleşme testi, Westerlund (2006) tarafindan geliştirilen çoklu yapısal kırılmalı panel eşbütünleşme testidir. Bu test, McCoskey ve Kao'nun LM testine dayalı bir testtir. Hem sabitte hem trendde birden çok yapısal kırılmaya izin veren bu testte sıfır hipotez eşbütünleşmenin olduğunu, alternatif hipotez ise eşbütünleşme ilişkisinin olmadığını ifade etmektedir (Westerlund, 2006: 102). $i=1, \ldots, N$ yatay kesit boyutunu ve $t=1, \ldots, T$ zaman boyutunu göstermek üzere, Westerlund aşağıdaki denklemler sisteminden hareket etmiştir (Westerlund, 2006: 103):

$$
\begin{gathered}
y_{i t}=z_{i t}^{\prime} \gamma_{i j}+x_{i t}^{\prime} \beta_{i}+e_{i t} \\
e_{i t}=r_{i t}+u_{i t} \\
r_{i t}=r_{i t-1}+\phi_{i} u_{i t}
\end{gathered}
$$

Burada $x_{i t}=x_{i t-1}+v_{i t} \mathrm{~K}$ boyutlu bağımsız değişken vektörü ve $z_{i t}$ deterministik bileşen vektörü; bunlara karşılık gelen parametre vektörleri ise sırayla $\beta_{i}$ ve $\gamma_{i j}$ 'dir. $j=1, \ldots, M_{i}+1$ indisi, yapısal kırılmaları belirtmek üzere kullanılmaktadır. Teste ilişkin sıfır hipotez ve alternatif hipotez aşağıdaki gibi ifade edilmektedir (Westerlund, 2006: 105):

$H_{0}: \phi_{i}=0 \quad \forall i \in i=1, \ldots, N$

$H_{1}: \phi_{i} \neq 0 ; \quad i=1, \ldots, N_{1}$ için ve $\phi_{i}=0 ; i=N_{1}+1, \ldots, N i$ çin

Test sonucunda iki farklı test sonuç elde edilmektedir. Bu sonuçlardan asimptotik olasılık değeri uzun dönem ilişkisini temsil eden denkleme ait kalıntılarda yatay kesit bağımlılığ olmaması durumunda, bootstrap olasılık değeri ise söz 
Yapısal Kırılmalar Altında Ticari Açıklı̆̆ın ve Doğrudan Yabancı Sermaye Yatırımlarının İstihdam Üzerindeki Etkisinin İncelenmesi: E7 Ülkeleri Örneği

konusu kalıntılarda yatay kesit bağımlılı̆g olması durumunda dikkate alınmaktadır. Westerlund (2006: 127), yatay kesit bağımlılığı halinde bootstrap yaklaşımının dirençli sonuç verdiğini göstermiştir. Bu test aynı zamanda değişkenler arasındaki uzun dönemli ilişkide meydana gelen yapısal kırılma tarihlerini de vermektedir.

Eşbütünleşme testi sonucunda değişkenler arasında uzun dönemli ilişki olduğu sonucuna ulaşıldıktan sonra, uzun dönem eşbütünleşme katsayılarının tahmini gerçekleştirilmektedir. Yatay kesit bağımlılı̆̆ olması durumunda eşbütünleşme katsayılarını tahmin etmeye yönelik olarak ilk olarak Pesaran tarafından CCE (Common Correlated Effects - Ortak İlişkili Etkiler) yöntemi geliştirilmiştir. Bu yöntemde eşbütünleşme katsayıları, önce bireysel eşbütünleşme katsayılarının tahmin edilip, daha sonra bu bireysel eşbütünleşme katsayılarının aritmetik ortalaması alınarak elde edilmektedir. Ancak panelde yer alan birimlerin panelin geneli üzerindeki etkilerinin farklı olmasının muhtemel olması nedeniyle, yine yatay kesit bağımlılığı göz önünde bulunduran ancak panelin geneline ait sonuç ve bireysel katsayıların ağırlıklandırılması yoluyla grup etkisinin hesaplandığ 1 bir yöntem geliştirilmiştir. AMG (Augmented Mean Group-Genişletilmiş Ortalama Grup) adı verilen ve Eberhardt ve Bond tarafindan geliştirilen bu yöntem, bu yönüyle CEE yönteminden daha güvenilirdir. AMG yöntemi aynı zamanda serilerdeki ortak faktörleri ve ortak dinamik etkileri göz önünde bulundurmakta, hata terimiyle ilgili içsellik probleminde de kullanılabilmektedir (Göçer, 2013b: 233).

İzlenen ekonometrik metodolojiye ilişkin bu bilgilerin ardından, izleyen bölümde elde edilen bulgular sunulmakta ve tartışılmaktadır.

\section{Bulgular}

Ekonometrik metodoloji kısmında değinildiği gibi, ekonometrik analizlerde değişkenlere birim kök testi uygulanmadan önce hangi kuşak birim kök testi tercih edilmesi gerektiğini tespit etmek amacıyla serilere yatay kesit bağımlılı̆̆ testi uygulanmaktadır.

Tablo 3: Değişkenlere ait yatay - kesit bağımlıllı̆ı testi sonucu

\begin{tabular}{|c|c|c|c|c|c|c|}
\hline \multirow{2}{*}{ Değişkenler } & \multicolumn{2}{|c|}{ CDLM $_{1}$} & \multicolumn{2}{c|}{ CDLM $_{2}$} & \multicolumn{2}{c|}{ LM $_{\text {adj }}$} \\
\cline { 2 - 7 } & $\begin{array}{c}\text { Test } \\
\text { istatistiği }\end{array}$ & p değeri & $\begin{array}{c}\text { Test } \\
\text { istatistiği }\end{array}$ & $\begin{array}{c}\mathbf{p} \\
\text { değeri }\end{array}$ & $\begin{array}{c}\text { Test } \\
\text { istatistiği }\end{array}$ & $\begin{array}{c}\mathbf{p} \\
\text { değeri }\end{array}$ \\
\hline İstihdam & 97.39 & 0.000 & 10.71 & 0.000 & 10.56 & 0.000 \\
\hline DYY & 263.42 & 0.000 & 36.33 & 0.000 & 36.18 & 0.000 \\
\hline Açıklık & 130.61 & 0.000 & 15.83 & 0.000 & 15.69 & 0.000 \\
\hline
\end{tabular}

Tablo 3 'te yer alan sonuçlar uygulanan her üç test için de bütün serilerde yatay kesit bağımlılı̆̆ olduğunu göstermektedir. Yani her bir seride yatay kesit birimleri arasında korelasyon söz konusudur. Diğer bir ifadeyle, ülkelerden birinde meydana gelecek olan bir şok diğer ülkeleri de etkileyecektir. Birim kök testi seçiminde, bu hususun göz önünde bulundurulması gerekmektedir. Bu çalışmada yatay kesit bağımlılığ 1 dikkate alan ikinci kuşak birim kök testlerinden MADF testi kullanılmıştır. MADF testi sonuçları Tablo 4'te yer almaktadır. 
Tablo 4: Birim kök testi sonucu

\begin{tabular}{|c|c|c|}
\hline Değişkenler & MADF istatistiği & Kritik değer (0.05) \\
\hline İstihdam & 19.996 & 31.844 \\
\hline$\Delta$ İstihdam & 90.227 & 33.168 \\
\hline DYY & 25.002 & 31.844 \\
\hline$\Delta$ DYY & 290.352 & 33.168 \\
\hline Açıklık & 57.339 & 31.844 \\
\hline
\end{tabular}

Birim kök testi sonuçlarının yer aldığ 1 Tablo 4 incelendiğinde, istihdam ve $D Y Y$ değişkenlerinin düzeyde birim köklü olduğu ve birinci farkı alındığında durağanlaştığı görülmektedir. Açıklık değişkeni ise düzeyde durağandır. Değişkenler arasındaki eşbütünleşme ilişkisinin incelenebilmesi için hangi kuşak eşbütünleşme testinin seçileceğine, modellere ait kalıntıların yatay kesit bağımlılığı içerip içermediğine bakılarak karara verilmektedir. Bu amaçla Model (1) ve Model (2)'nin kalıntılarına uygulanan yatay kesit bağımlılığı testi sonuçları Tablo 5'te yer almaktadır.

Tablo 5: Modellere ait yatay kesit bağımlılı̆̆ı testi sonucu

\begin{tabular}{|c|c|c|c|c|}
\hline \multirow{2}{*}{ Modeller } & \multicolumn{2}{|c|}{ CDLM1 } & \multicolumn{2}{c|}{ LMadj $_{\text {adj }}$} \\
\cline { 2 - 5 } & $\begin{array}{c}\text { Test } \\
\text { istatistiği }\end{array}$ & p değeri & $\begin{array}{c}\text { Test } \\
\text { istatistiği }\end{array}$ & $\begin{array}{c}\mathbf{p} \\
\text { değeri }\end{array}$ \\
\hline Model 1: İstihdam=f(DYY) & $82.87^{*}$ & 0.00 & $25.88^{*}$ & 0.00 \\
\hline Model 2: İstihdam=f(Açıklık) & $25.54^{*}$ & 0.00 & $81.64^{*}$ & 0.00 \\
\hline
\end{tabular}

*, 0.01 anlamlılık düzeyini ifade etmektedir.

$\mathrm{Bu}$ sonuçlar her iki modelde de yatay kesit bağımlılığı olduğunu göstermektedir. Dolayısıyla eşbütünleşme ilişkisi incelenirken, yatay kesit bağımlılığ 1 dikkate alan ikinci kuşak eşbütünleşme testlerinin seçilmesi gerekmektedir.

Model (1) ve Model (2) serilerin durağanlık mertebeleri açısından değerlendirildiğinde, uygulanacak olan eşbütünleşme testlerinin farklılaştığı da görülebilir. Her iki değişkenin de I(1) olduğu Model (1)'de eşbütünleşme ilişkisi Westerlund yapısal kırılmalı eşbütünleşme testi ile; bağımlı değişkenin I(1) ve bağımsız değişkenin I(0) olduğu Model (2)'deki eşbütünleşme ilişkisi ise DurbinHausman testi ile incelenmiştir. Sonuçlar Tablo 6' da yer almaktadır.

Tablo 6: Eşbütünleşme testi sonuçlart

\begin{tabular}{|c|c|c|c|c|c|c|}
\hline \multicolumn{4}{|c|}{ Westerlund testi [İstihdam=f(DYY)] } & \multicolumn{3}{|c|}{$\begin{array}{c}\text { Durbin - Hausman } \\
\text { [İstihdam=f(Açıklı)] }\end{array}$} \\
\hline & $\begin{array}{c}\text { LM } \\
\text { istatistiği }\end{array}$ & $\begin{array}{c}\text { Asimptotik } \\
\text { p-değeri }\end{array}$ & $\begin{array}{c}\text { Bootstrap } \\
\text { p-değeri }\end{array}$ & & $\begin{array}{c}\text { Test } \\
\text { istatistiği }\end{array}$ & p-değeri \\
\hline $\begin{array}{c}\text { Sabitte } \\
\text { kırılma }\end{array}$ & 3.823 & 0.000 & 0.870 & dh_g & -0.185 & 0.573 \\
\hline $\begin{array}{c}\text { Sabitte ve } \\
\text { trendde } \\
\text { kırılma }\end{array}$ & 38.809 & 0.000 & 0.668 & dh_p & -0.597 & 0.725 \\
\hline
\end{tabular}


Yapısal Kırılmalar Altında Ticari Açıklı̆̆ın ve Doğrudan Yabancı Sermaye Yatırımlarının İstihdam Üzerindeki Etkisinin İncelenmesi: E7 Ülkeleri Örneği

Westerlund çoklu yapısal kırılmalı eşbütünleşme testi sonucu değerlendirilirken, yatay kesit bağımlılığ 1 olmasından dolayı bootstrap p-değeri dikkate alınmaktadır. $\mathrm{P}$ değerinin 0,05 'ten büyük olmasından dolayı, eşbütünleşmenin varlığını ifade eden sıfir hipotezi reddedilememektedir. Yani hem sabitte hem sabitte ve trendde yapısal kırılma koşulu altında istihdam ve DYY değişkenleri arasında eşbütünleşme ilişkisi söz konusudur. Farklı durağanlık mertebelerine sahip değişkenler arasında eşbütünleşmenin varlığını sınamaya imkan sağlayan Durbin-Hausman testi sonuçları ise istihdam ve açıklık değişkenleri arasında eşbütünleşme ilişkisi olmadığını göstermektedir. Birimlere ait zaman boyutu $\mathrm{T}=25$ olduğu için, en çok 2 kırılmaya izin verilerek gerçekleştirilen analiz sonucunda elde edilen ve istihdam ve DYY değişkenleri arasında yapısal kırılmalı eşbütünleşme ilişkisine ilişkin olan kırılma tarihleri Tablo 7'de verilmektedir.

Tablo 7: Eşbütünleşme denkleminde tespit edilen yapısal kırılma tarihleri

\begin{tabular}{|c|c|c|c|c|}
\hline \multirow{2}{*}{ Ülkeler } & \multicolumn{2}{|c|}{ Sabitte kırılma } & \multicolumn{2}{c|}{ Sabitte ve trendde kırılma } \\
\cline { 2 - 5 } & $\begin{array}{c}\text { Kırılma } \\
\text { sayısı }\end{array}$ & Kırılma tarihi & Kırılma sayısı & Kırılma tarihi \\
\hline Brezilya & 1 & 2001 & 2 & 1998,2012 \\
\hline Çin & 2 & 2001,2006 & 1 & 2001 \\
\hline Endonezya & 2 & 2001,2008 & 2 & 2000,2006 \\
\hline Hindistan & 2 & 2001,2010 & 2 & 2004,2011 \\
\hline Meksika & 1 & 1997 & 0 & - \\
\hline Rusya & 1 & 2006 & 2 & 1998,2006 \\
\hline Türkiye & 2 & 2000,2010 & 2 & 1997,2004 \\
\hline
\end{tabular}

Kırılma tarihleri incelendiğinde, sabitte kırılmanın olduğu sonuçlarda 2001 yılında birçok ülkede kırılma gerçekleştiği göze çarpmaktadır. Bu yılın küresel anlamda taşıdığı önem, ABD'de gerçekleştirilen 11 Eylül saldırıları olarak değerlendirilebilir. Çin açısından bu yılın başka bir önemi daha vardır. Zira 2001 yılı Çin'in Dünya Ticaret Örgütü'ne üye olduğu yıldır. Endonezya'da, küresel krizin başladığı yıl olan 2008 yılında yapısal kırılma gerçekleşmiştir. Türkiye'de ise 2000 krizinin $D Y Y$ ve istihdam değişkenleri arasındaki uzun dönemli ilişkide kırılmaya sebep olduğu söylenebilir. Sabitte ve trendde kırılmanın dikkate alındığı tahmin sonuçları ise Çin'de 2001 yılında tek bir kırılma olduğunu; Meksika'da ise kırılma olmadığını göstermektedir. Rusya'da 1998 krizinin yaşandığı dönemde söz konusu uzun dönemli ilişkide bir yapısal kırılma gerçekleştiği görülmektedir. $\mathrm{Bu}$ sonuçlardan, genel olarak gerek küresel gerek ülkeye özgü krizlerin $D Y Y$ ve istihdam değişkenleri arasındaki uzun dönemli ilişkide kırılmaya sebep olduğu çıkarımı yapılabilir.

Eşbütünleşme ilişkisinin tespit edilmesinin ardından eşbütünleşme katsayıları AMG yöntemi ile tahmin edilmiştir. Her ne kadar gelişen ülkeler topluluğu olarak isimlendirilse de topluluk içerisinde yer alan ülkeler gerek ekonomik gerek sosyokültürel yapı açısından oldukça farklı dinamiklere sahiptirler. Bu sebeple ülkeler 
arasında heterojenlik olduğu ön kabulünden hareketle, her bir ülkeye ilişkin eşbütünleşme katsayısı ayrı ayrı tahmin edilmiştir.

Tablo 8: Eşbütünleşme katsayılarının tahmin sonuçları

\begin{tabular}{|c|c|c|c|}
\hline Ülkeler & Katsayı & Test istatistiği & p değeri \\
\hline Brezilya & $-0.053^{* * *}$ & -1.79 & 0.073 \\
\hline Çin & $0.457 *$ & 5.11 & 0.000 \\
\hline Endonezya & 0.099* & 4.72 & 0.000 \\
\hline Hindistan & $-0.511 *$ & -13.84 & 0.000 \\
\hline Meksika & 0.008 & 0.48 & 0.632 \\
\hline Rusya & $0.169^{* *}$ & 2.55 & 0.011 \\
\hline Türkiye & 0.027 & 0.35 & 0.726 \\
\hline Panel & 0.028 & 0.26 & 0.798 \\
\hline
\end{tabular}

Tablo 8'deki sonuçlara bakıldığında, panelin heterojen olduğu varsayımıyla panelin geneli için yapılan katsayı tahmininin istatistiksel olarak anlamlı olmadığı görülmektedir. Eşbütünleşme katsayısı Brezilya için 0.10; Çin, Endonezya ve Hindistan için 0.01; Rusya için ise 0.05 anlamlılık düzeyinde istatistiksel olarak anlamlıdır. Meksika ve Türkiye için ise bu iki değişken arasında istatistiksel olarak anlamlı bir ilişki söz konusu değildir. Katsayıların anlamlı olduğu ülkelerden Çin, Endonezya ve Rusya'da $D Y Y$ değişkeninin istihdam üzerindeki uzun dönem etkisi pozitif iken; Brezilya ve Hindistan'da bu etki negatiftir. DYY değişkeninin istihdam üzerinde pozitif etkiye sebep olduğu ülkeler içerisinde bu etkinin en yüksek olduğu ülke Çin'dir.

\section{Sonuç ve Değerlendirme}

Son dönemde ülkelerin korumacı politikalar uygulamaya başlamasına rağmen küreselleşmenin en yüksek hıza ulaştığı günümüzde, özellikle gelişen ülkelerin büyüme potansiyellerini kullanabilmeleri açısından küresel değer zincirinin bir halkası olmaları önem kazanan bir husustur. Bu kapsamda, gelişen ülkeler küresel üretim ve küresel ticaret faaliyetlerinin bir parçası olma yönünde dışa açılmacı politikalar izlemektedirler.

Bu çerçevede, bu çalışmada 'Gelişen 7' ülkeleri olarak bilinen Brezilya, Çin, Hindistan, Endonezya, Meksika, Rusya ve Türkiye'de, bir ülkenin dışa açıklığının ölçütü olarak nitelendirilebilen ticari açıklık ile doğrudan yabancı sermaye yatırımlarının hasıladaki payı değişkenlerinin, istihdam üzerinde etkili olup olmadığ1 1993-2017 dönemi kapsamında analiz edilmiştir. Eşbütünleşme analizi uygulanan çalışmada, ticari açıklık ile istihdam arasında uzun dönem ilişkisi tespit edilemezken, doğrudan yabancı sermaye yatırımlarının hasıladaki payı ile istihdam arasında uzun dönemli bir ilişki olduğu tespit edilmiştir. $\mathrm{Bu}$ sonuç, Gelişen-7 ülkelerinde küreselleşmenin iki kaçınılmaz sonucu olan doğrudan yabancı sermaye yatırımları ve ticari açıklıktan, reel üretime yönelik yapılan doğrudan yabancı sermaye yatırımlarının istihdam üzerinde etkili olduğunu ortaya koymaktadır. 
Yapısal Kırılmalar Altında Ticari Açıklı̆̆ın ve Doğrudan Yabancı Sermaye Yatırımlarının İstihdam Üzerindeki Etkisinin İncelenmesi: E7 Ülkeleri Örneği

Her ne kadar bir ülke grubu olarak tanımlansa da E7 ülkeleri oldukça farklı sosyal, kültürel ve ekonomik dinamiklere sahiptirler. Bu sebeple, ülkelerin heterojen oldukları kabulünden hareketle, her bir yatay-kesit için uzun dönem katsayıları tahmin edilmiştir. Doğrudan yabancı sermaye yatırımlarının hasıladaki payının istihdam üzerindeki uzun dönemli etkisinin Çin, Endonezya ve Rusya'da pozitif iken; Hindistan ve Brezilya'da negatif olduğu görülmüştür. Bu farklılığın sebepleri kurumsal, ekonomik, sosyal ve kültürel birçok faktörle ilişkili olabilir. Bununla birlikte, doğrudan yabancı yatırımların ev sahibi ülkede hangi sektörlere yöneldiğine bakmak, bu sonucun olası nedenlerini ortaya koyabilir. İlk olarak, Hindistan için 2000 yılı Ocak ayından 2019 yılı Haziran ayına kadar ülkeye giren doğrudan yabancı sermayenin sektörel dağılım oranları kümülatif olarak incelendiğinde; ilk sırada \% 17.6'lık pay ile hizmet sektörünün yer aldığı, bunu \%9 ile bilgisayar yazılım \& donanım, \% 8.5 ile telekomünikasyon, \%5.7 ile inşaat ve \%5.5 ile ticaret sektörlerinin izlediği görülmektedir? ${ }^{7}$. Bu bağlamda, Hindistan'ın aldığı doğrudan yabancı sermaye yatırımlarının reel anlamda üretken kesimden ziyade daha çok hizmet üretiminde yoğunlaştığ 1 ifade edilebilir. Brezilya için elde edilen istatistikler incelendiğinde; 2010 yılında \%12 ile en yüksek oranda yatırım alan sektör olan ticaret sektörüne ait payın 2015 yılında \%17'ye yükseldiği görülmektedir. Finansal hizmetler sektörünün 2010 yıllnda \%6 olan pay1 2015 y1lında $\% 10$ 'a; bilgi ve teknoloji hizmetlerinin 2010 y1lında \%3 olan payı 2015 'te $\% 5$ 'e; inşaat faaliyetlerinin 2010 yılında \%2 olan payı ise 2015 y1lında \%4'e yükselmiştir. 2010 y1lında \%14 paya sahip olan gayrimenkul sektörünün payı 2015 yılında \%10'a düşmekle birlikte, gelen doğrudan yabancı sermaye yatırımları içerisinde hala önemli bir paya sahip görünmektedir (Banco Central do Brasil, 2018: 23). Özetle, Brezilya'da da ülkeye gelen yabancı sermaye yatırımlarının reel üretken sektörlerden ziyade istihdam yaratma potansiyeli imalat sanayii kadar güçlü olmayan hizmet sektörüne yöneldiği görülmektedir.

Bunlara ilaveten, çoklu yapısal kırılmalı eşbütünleşme testi sonucu elde edilen bulguların ortaya koyduğu bir diğer sonuç, doğrudan yabancı sermaye yatırımları ve istihdam değişkenleri arasındaki uzun dönemli ilişkinin hem küresel hem lokal krizlerden etkilendiği şeklindedir. Yani söz konusu krizler, doğrudan yabancı sermaye ve istihdam arasındaki uzun dönemli ilişkide kırılmaya sebep olmaktadır. $\mathrm{Bu}$ da doğrudan yabancı sermaye yatırımlarının istihdam üzerindeki etkisinin krizler karşısında kırılgan olduğunu göstermektedir.

Çalışma bulguları bir bütün olarak değerlendirildiğinde, gelişen ülkeler açısından ülkeye gelen doğrudan yabancı sermaye yatırımlarının hacmi kadar, bu yatırımların hangi alanlarda faaliyette bulunduklarının da önem taşıyan bir unsur olduğu belirtilebilir. Özellikle, doğrudan yabancı sermaye yatırımlarının istihdam etkisi dikkate alındığında, ülkelerin üretken reel kesime gelecek doğrudan yabancı yatırımları teşvik etmeleri önem kazanmaktadır.

${ }^{7}$ Çevrimiçi, https://dipp.gov.in/sites/default/files/Table_No_4_JULY_19.pdf (31.12.2019) 


\section{Kaynaklar}

Asiedu, E., Brempong, K. G. (2008) "The Effect of the Liberalization of Investment Policies on Employment and Investment of Multinational Corporations in Africa", African Development Review, 20(1), ss.49-66.

Ayaş, N. ve Çeştepe, H. (2010) "Dış Ticaretin İstihdam Üzerindeki Etkileri: Türk İmalat Sanayi Örneği”, Süleyman Demirel Üniversitesi İIBF Dergisi, 15(2), ss.259-281.

Baldwin, R.E. (1995) "The Effects of Trade And Foregn Direct Investment On Employment and Relative Wages", NBER Working Paper 5037.

Banco Central do Brasil (2018). Foreign Direct Investment in Brazil Report.

Breuer, J.B., Mcnown, R., Wallace, M. (2002) "Series-specific Unit Root Tests with Panel Data", Oxford Bulletin of Economics and Statistics 64 (5), ss.527-546.

Brooks, C. (2014), Introductory Econometrics for Finance, 3rd edition, Cambridge University Press, United Kingdom.

Doğan, B., Can. M., "Doğrudan Yabancı Yatırımlar İstihdamı Etkiliyor Mu?: Türkiye Örnekleminde ARDL Sınır Testi Yaklaşımı”, Finans Politik ve Ekonomik Yorumlar Dergisi 53 (614).

Gereffi, G. (2015). "Global Value Chains, Development and Emerging Economies", Research, Statistics and Industrial Policy Branch Working Paper, UNIDO, No. 18/2015.

Goaied, M. Ve Sassi, S. (2015). Trade liberalisation and employment intensity of sectoral output growth: Lessons from Tunisia. The Economic and Labour Relations Review, 26(2), pp. 261275. https://doi.org/10.1177/1035304615579833

Gozgor, G. (2014) "The Impact of Trade Openness on The Unemployment Rate in G7 Countries", Journal of International Trade \& Economic Development, 23(7), pp. 1018-1037; doi: 10.1080/09638199.2013.827233

Göçer, İ.(2013a). "Seçilmiş OECD Ülkelerinde Bütçe Açıklarının Sürdürülebilirliği: Yatay Kesit Bağımlılı̆̆1 Altında Panel Eş-bütünleşme Analizi”, Journal of Yaşar University, 30 (8), pp. 5086-5104.

Göçer, İ. (2013b). "Ar-Ge Harcamalarının Yüksek Teknolojili Ürün İhracatı, Dış Ticaret Dengesi ve Ekonomik Büyüme Üzerindeki etkileri”, Maliye Dergisi, $165,215-240$.

Göçer İ. ve Peker O. (2014). "Yabancı Doğrudan Yatırımların İstihdam Üzerindeki Etkisi: Türkiye, Çin ve Hindistan Örneğinde Çoklu Yapısal Kırılmalı Eşbütünleşme Analizi”, 21(1), ss.107-123.

Greenaway, D.,H. R.C. \& Wright, P. (1999) "An Empirical Assessment of The Impact of Trade On Employment İn The United Kingdom," European Journal of Political Economy", Elsevier, September 15(3), pp. 485-500.

Gül, E. ve Kamacı, A. (2012) "Dış Ticaretin İstihdam Üzerindeki Etkileri: Bir Panel Veri Analizi”, Anadolu Üniversitesi Sosyal Bilimler Dergisi,12(4). 
Yapısal Kırılmalar Altında Ticari Açıklı̆̆ın ve Doğrudan Yabancı Sermaye Yatırımlarının İstihdam Üzerindeki Etkisinin İncelenmesi: E7 Ülkeleri Örneği

Hasan, R., D. Mitra, P. Ranjan \& R.N. Ahsan (2012), "Trade Liberalization and Unemployment: Theory and Evidence from India", Journal of Development Economics, 97(2), pp. 269-280; doi: 10.1016/j.jdeveco.2011.04.002

Hawksworth, J.ve Cookson, G.(2008). The World in 2050 - Beyond The Brics: A Broader Look At Emerging Market Growth Prospects, PricewaterhouseCoopers LLP, https://www.pwc.com/la/en/publications/ assets/world 2050 brics.pdf (14.06.2019).

Hiro L., D. R.-Holst, (1994). Trade Liberalization and Employment Linkages in the Pacific Basin, OECD Development Centre Working Papers 94, OECD Publishing.

H.Yang., Shi F., Wang, J., Jing, Z.(2019). "Investigating the relationship between financial liberalization and capital flow waves: A panel data analysis", International Review of Economics and Finance,59, pp.120-136.

Janiak, A. (2006) Does Trade Liberalization Lead to Unemployment? Theory and Some Evidence, ECARES, Jop Market Paper, pp. 1-50.

Jenkins, R.O. ve Sen, K. (2006). International Trade and Manufacturing Employment in the South: Four Country Case Studies, Oxford Development Studies,34, pp.299-322.

Jenkins, R. (2006). Globalization, foreign investment and employment in Viet Nam. Transnational Corporations, 15 (1), pp.115-142.

Karaçor, Z. ve T.B. Saraç (2011), "Dış Ticaret İle Sanayi Sektörü İstihdam Oranı Arasındaki Kısa Ve Uzun Dönem İlişkisi: Türkiye Örneği (1963-2009)", Yönetim ve Ekonomi, 18(2), ss.181-194.

Kıran, B.ve Güriş, B. (2011), "Türkiye'de Ticari ve Finansal Dışa Açıklığın Büyümeye Etkisi: 1992-2006 Dönemi Üzerine Bir İnceleme" Anadolu Üniversitesi, Sosyal Bilimler Dergisi,Eskişehir, (2), ss.69-80.

Kien, T. N. Ve Heo, Y. (2009) "The Developing Economies Impacts Of Trade Liberalization On Employment İn Vietnam: A System Generalized Method Of Moments Estimation", The Developing Economies, 47(1), pp. 81-103.

Megbowon, E., Ngarava, S , Mushunje, A .(2016) "Foreign Direct Investment Inflow, Capital Formation and Employmentim South Africa: A Time Series Analysis, International Journal of Economics and Finance Studies, 8(2), pp.175-189.

Özel, H . (2012). "Küreselleşme Sürecinde Ticari ve Finansal Açıklığın Ekonomik Büyüme Üzerine Etkisi: Türkiye Örneği”. Yönetim Bilimleri Dergisi, 10 (19), ss.21-43.

Pan, C., Chang, T. ve Wolde-Rufael, Y. (2015) "Military Spending and Economic Growth in the Middle East Countries: Bootstrap Panel Causality Test", Defence and Peace Economics, 26 (24), 443-456.

Pesaran, M. H. (2004) "General Diagnostic Tests for Cross Section Dependence in Panels", CWPE, 0435.

Pesaran, M. H., (2007) "A Simple Panel Unit Root Test in the Presence of CrossSection Dependence”, Journal of Applied Econometrics, 22, ss. 265-312. 
Polat, Ö. ve Uslu E.E. (2010), "Türkiye İmalat Sanayinde Dı̧̧ Ticaretin İstihdam Üzerindeki Etkisi”, Gaziantep Üniversitesi Sosyal Bilimler Dergisi, 9(3), ss.489-504.

PricewaterhouseCoopers (PwC) (2017). "The Long View How Will the Global Economic Order Change by 2050?”, (çevrimiçi) https://www.pwc.com.tr/tr/publications/arastirmalar/assets/world-in2050/2050-de-dunya-raporu.pdf, (01.01.2020)

Rhys J.(2006) "Globalization, Foreign Investment and Employment in Viet Nam" Transnational Corporations,15(1), ss.115-142.

Sakurai, K. (2004) "How Does Trade Affect The Labor Market? Evidence From Japanese Manufacturing", Japan and the World Economy, 16(2),139-161.

Sandalcılar, A.T. \& N.İ.T. Yalman (2012), "Türkiye'de Dış Ticaretteki Serbestleşmenin İşgücü Piyasaları Üzerindeki Etkileri”, Eskişehir Osmangazi Üniversitesi İktisadi ve İdari Bilimler Dergisi, 7(2), 49-65.

Spilimbergo, A., Londono, J. L. ve Szekely, M.(2003), Income Distribution, Factor Endowments, and Trade Openness, Toward Pro-Poor Policies Aid, Institutions, and Globalization, Annual World Bank Conference on Development Economics Europe, Ed. Bertil Tungodden, Nicholas Stern, Ivar Kolstad, The World Bank

Şener, F. (2001) "Schumpeterian Unemployment, Trade and Wages", Journal of International Economics,54(1) ss. 119-148.

Taylor, M. P., ve Sarno, L., (1998) "The Behavior of Real Exchange Rates During the Post-Bretton Woods Period", Journal of International Economics, 46, 281-312.

Tawfik, T., Alkhateeb, Y. Mahmood, H., Ahmad, Z., Sultan and Ahmad N., (2017) "Trade Openness and Employment Nexus in Saudi Arabia", International Journal of Economic Research, 14(14), ss.59-66.

Taymaz, E. (1999), Trade Liberalization and Employment Generation: The Experience of Turkey in the 1980s, Ed. Ana Revenga, Turkey: Economic Reforms, Living Standards, and Social Welfare Study, Vol II Technical Papers, Washington, D.C.:World Bank.

Westerlund, J. (2006). "Testing for Panel Cointegration with Multiple Structural Breaks", Oxford Bulletin of Economics and Statistics, 68 (1), ss.101-132.

Yanıkkaya, H. (2013), "Is trade liberalization a solution to the unemployment problem?", Portuguese Economic Journal, 12(1), 57-85; doi:10.1007/s10258013-0088-9

Yerdelen Tatoğlu, F. (2013), İleri Panel Veri Analizi Stata Uygulamalı, İkinci bask1, Beta, İstanbul.

Yıımaz, A., Altay H. (2016), "Ticari Dışa Açıklık ile İşsizlik Arasındaki Eşbütünleşme İlişkisi: G-8 Ülkeleri İçin Panel Veri Analizi”, https://www.academia.edu/29859163/THE_COINTEGRATION_RLATIONSHIP_ BETWEEN_TRADE_OPENNESS_AND_UNEMPLOYMENT_RATE

https://dipp.gov.in/sites/default/files/Table_No_4_JULY_19.pdf (31.12.2019) 